\title{
The Obsolescence of Man in The Digital Society
}

\author{
Dominique Maillard ${ }^{1, *}$ \\ ${ }^{1}$ Université Paris Est Créteil, Paris \\ ${ }^{1}$ Dmillard@stust.edu.ee* \\ *corresponding author
}

(Received July 7, 2021 Revised July 22, 2021 Accepted August 29, 2021, Available online September 1, 2021)

\begin{abstract}
Commenting on the limitations of Man after the moral disasters of World War II and the logics of production inherent to the second industrial revolution, GuntherAnders had concluded to the "obsolescence of Man". Anders pointed to the "Promethean gap" that exists between Man as an instrument among other instruments and his ability at encompassing the superior efficiency of the products he churned out. The new realities of production and trade, of human body engineering and power politics, as well as the shift from ownership to access, in the "digital society" hint that Gunther Anders's remark are still valid in the context of the third industrial revolution based on the Knowledge economy.
\end{abstract}

Keywords: Promethean Pass; Innovation; Big data; Digital society; Cyber security;

\section{Introduction}

For the French historian Fernand Braudel, the most difficult task is to understand contemporary history, to understand scientifically and significantly what actually happened in the world around it, away from short-term democratic and political debates. The ontological function of the Chinese Emperor was to ensure that the social order conforms to the cosmic order. In their divergent philosophical endeavors to rebuild a Chinese society threatened by corruption of power and moral weakness, both Confucius and Lao-Tzu developed precepts that would hopefully guarantee respect for the social order of things for the former, and respect for the natural order of things. thing for later. However, it is debatable to ensure that the general notion of "human nature" is present in classical Chinese thinking. As the French synologist Anne Cheng pointed out, the cumulative process of Chinese thought - as opposed to the dialectical approach of Greek philosophy - led Chinese thinkers to "reason not better, but to the better life of one's human nature in harmony with the world. "Because the social order of things coalesces and dissolves into the cosmic order. In short, the structural order of tian is the same as the structural order of ren since they finally formed one.

Later, in the West, the Church attempted during the Renaissance a philosophical, neo-platonic, synthesis which taken from the philosophical legacy of ancient Greece which assigned to it the dual benefit of imagining with the Greek philosopher Plato on the one hand the perfect concept that the human soul perceives as a reflection of an invisible world on the walls of a cave, while on the other the Greek philosopher Aristotle proposes to think about back from observing society $\mathrm{n}$ the material world as it is with thoughts to establish what will become the laws of physics. Theoretically, European humanism has been inherited from the Renaissance period - through thinkers from the Italian philosopher Pic de la Mirandole to the French philosophers Montaigne and Condorcet for example - the idea that the attainment of Man is the ontological goal of a free and open society. Conceptually, the "enhancement" of mankind has almost no limits so that the physical, intellectual, moral and political "perfection" of individuals through their "enhancement" will ultimately enable the collective, social progress of humanity as a whole.

Age of the Enlightenment, the Scottish philosopher John Locke established the theory of "natural rights" as a new basis for political and social order. Man holds his "political rights" from the "natural" order given by his Creator or by Nature. The French philosopher Rousseau argued that Natural law and frugal living should be the source of the new "social contract," whereas, on the other hand, the French philosopher Voltaire chose Reason and the market as the 
basis for merit-based human institutions to rule freely. and open society. At the end of the second decade of the 21 st century, the decisive advances made in biotechnology, nanotechnology, big data management, genetics, robotics and artificial intelligence have challenged traditional notions of humanism that place Humans at the center of social construction and specific functions. medicine in the healing of the human body. Transhumanism has accepted the idea that "perfection" can include the eradication of some genetic diseases that attack the human species by modifying human genes and the genetic transformation of animal pests that spread other diseases that are harmful to the human species. In addition, advances in robotics combined with artificial intelligence paved the way towards redefining the interface between humans and machines. Just as the second industrial revolution has modified the "soul" of people and changed their philosophy, digital societies everywhere are profoundly influencing the collective soul of society in the 21 st century.

A decade after the end of World War II, the thesis that GuntherAnders [1] defended in 1956 on the state of the world and the human condition after the second industrial revolution rests on three ideas: 1) mankind and the individuals who are part of it can no longer measure to the perfection of products produced by their own manufacturing industry; 2) human production has gone beyond the representations that humans are capable of forming from it and feels responsible for it individually; 3) furthermore, individuals no longer believe but what they are allowed to believe, or worse, believe what the elites want them to believe. GuntherAnders' thesis on the state of the postwar world and the human condition stems from the observation that after World War II and the dropping of the atomic bombs on the Japanese Empire on Hiroshima and Nagasaki, humanity has shown itself to be capable of self-reliance. destruction and that the individual has integrated that faculty as a new, almost anecdotal reality. Strikingly, Anders' critique of the new constraints arising from the technical forces of the human mind in the fifties finds resonance in criticism of the power of technology companies in the 21 st century.

In addition, said Anders in early 1956, the nascent "consumer society" had imposed its limits on human freedoms which had paled in the face of the reality of consumerism. What matters most is no longer human freedom, for Jean-Paul Sartre's theory of existentialism was still going to survive at that time, for example. What is important lies elsewhere, in the principles of the new world economic and social organization. According to Anders, the "real world" has become a tool in the hands of the elite in pursuing their macroeconomic goals. The originality of GuntherAnders' social critique of the 1950s was that it focused not on the social "alienation" of the people who were producing, or on the manner in which production was achieved, or even on the quantity produced, but on the nature of what was being produced. In this sense, Anders' critique remains relevant at the end of the second decade of the 21 st century, especially as it relates to the similarities that elites in today's marketplace make between innovation, technical obsolescence of products and means of production.

As far as Mancan is considered from his "instrument" point of view, he can be viewed as a "construction" - and one that is lacking in this respect. And, reasoned Anders, once this kind of categorization of humankind has been universally recognized, a philosophical perspective on human reality can be reversed: what has not been "built up" at all, can then reveal itself to be inadequate. It cannot be denied that in terms of force, speed and precision Man is inferior to his own machine and that the comparison between what he can achieve and what his "computational machine" can do is in his favor. Therefore, the education considered since the second industrial revolution is no longer Man as an instrument among other instruments, but Man as an instrument for other instruments. Humans have become an element in any built machine or fixed project. It is in this sense, thought Anders, that Man is "wrong," "inadequate," "unadjusted," for a second industry or digital society. [2]

Thus, the "digital revolution" has been producing new ideologies, such as the transhumanism and posthumanism projects, which firms, governments, the media, social networks, stockholders and stakeholders alike, have been quick to grapple with in the Knowledge-society. Like the previous generations confronted with rapid technological changes, the denizens of the "digitalized" world will have to meet the challenge of the "obsolescence of Man" and somehow reinvent the human kind, hopefully by subordinating the use of artificial intelligence to that of human intelligence. Meanwhile, it is worthwhile to examine what Gunther Anders used to call the "Promethean gap" and the "metamorphoses of the human soul" in the wake of technological change in the "digital society." 


\section{The "Promethean Gap" and The New Realities Of Production Processes in The "Digital Society"}

In general, so far, the Knowledge-Economy has translated into an economy driven by innovation. In general, so far, global management has been about globalization driven by free trade. In general, so far, Schumpeterian's destructive creations, which have replaced the post-WWII consensus on the Keynesian economy and the Welfare State, have endlessly produced new, job-destroying technologies over the past two decades, creating new skilled jobs in the digital world. world for those who can afford it. Meanwhile, advances in artificial intelligence have given rise to "robotic ranks", with machines now outperforming humans at work, or on trips or on chessboards, giving up more and more jobs. It's no wonder, then, that in the 2016 American presidential election, the natives, isolationists, nineteenth-century Americans turned into college-less American men and economically backsliding and rejecting white women. altogether the elite, the establishment, free trade, globalization and immigration.

\subsection{The mutations of human labor and the "metamorphoses of the human soul": the limits of human "representation" v. the creation of new product}

Some analysts, such as the French philosopher and academic Michel Serres, see a new global society, inventive and peaceful, democratic and ecological, dawning in our world. On the other hand, others suspect that our world is heading towards an unpleasant, even more subtle form of a "disciplinary society" - as the French philosopher Michel Foucault [3] calls it - than he traces from the 17th to the 20th centuries. Both Michel Serres and anthropologist André Leroi-Gourhan [4] describe the long story of humanity as a series of technical changes. From the beginning onwards, the changing status of mankind throughout history is associated with various phases of "externalization". Digital tools, instruments and networks metaphorically correspond to the different ages of mankind: the age of physics as an extension of the human skeleton, the age of thermodynamics as an extension of human energy, and the age of electricity as an extension of the nervous system.

The first phase came with an extension of the human skeleton with tools like flints and levers and then more sophisticated tools and instruments prolonging the human frame. The second phase involved the extension of devices enhancing human muscular strength and thermal energy, such as steam engines and motors driving loads. The third phase corresponds to the extension of the human nervous system with computers, social networks and digitized data. Thus, one of the features of the human species has always been its ability to en enhancing itself through artificial externalization. Likewise, the story of human language is closely linked with the extension of human knowledge can also be analyzed as a process of successive externalizations bringing about a further deepening of human thinking. Originally, human thought was limited by its exclusive reliance on oral expression. Then, the mastery of writing allowed an externalization of human memory and the function of symbolism, which anthropologist Jack Goody [5] associated with a new "graphic" way of reasoning. Later in the West, the generalization of the modernized version of the printing press inherited from China brought about deep transformations such as the advent of humanism and science in modern times. A quantification of the world enhanced a mathematical approach to understanding the material world, allowed for the expansion of commercial exchanges and fostered the European "great discoveries", which significantly increased cultural horizons worldwide, and opened up knowledge and understanding to new fields.

By the end of the 20th century, the generalized digitalization of human memory and the dramatic expansion worldwide communication, the creation of research engines sifting through «big data», the constant exchange of e-mails and the development of global social networks had emerged with a structure that could be analogically compared to a global externalized human nervous system. Michel Serres uses the decollation of Saint Denis's head as a metaphor for the externalization of human knowledge, a process which had started in human history a long time before the saint's martyrdom on the hill of Montmartre. Likewise, the invention of the computer would be the latest step in the externalization of human cognitive faculties such as memory, imagination and reason itself. Thus in our time, the human mind would finally be alleviated of the burden of memorization for good. Borrowing from Michel de Montaigne who preferred a "well-made" head to a well-filled "one during the first Revival of learning, Michel Serres sees a radical shift in access to knowledge in our global, connected society. All the members of the rising Millennials' generation, like Michel Serres's mutant creature, la petite poucette, a "digital native" who is frantically sending 
hundreds of daily messages with her two thumbs from her i-pad, have been soaking in the technologies of information and communication since birth. Thus concludes Michel Serres, in a world where young people have direct access to practically all of universal knowledge, the "well-filled" head has definitely given way to the "well-made" head, thus allowing at last full time for human creativity. and innovative thinking. However, this assumption is not fully taking the nature of the technological changes into account. As GuntherAnders had already noted in the 1950s, the "Promethean gap" illustrated the limits of human "representation": the loss of individual identity and responsibility with theyau human kind's capability of self-destruction thanks to the atom bomb and the industrialization of human genocide with the Holocaust in Europe.

Commenting on the "metamorphoses of the human soul" during the second industrial revolution, GuntherAnders maintained that one of the major changes in the collective psyche was the inability of people to keep spiritually up to date with the progress of human production. What Anders meant was that human minds fell short of adapting to the new products churned out by the process of innovation. In other words, Anders felt that the implications of new human instruments are always ahead of what human minds can grasp at the time of their invention. It is this lack of "synchronization" between Man himself and the world he produces that Anders called the "Promethean gap." Man and his creation do not move in step. Anders noted that Marxism had taken only one aspect of this "gap" into account: the difference of rhythm between the developments of what Marx saw as the "superstructure" and the "infrastructure." However, Anders thought that there were other social phenomena illustrating the "Promethean gap," such as the gap between the realities of production relations to "ideological" theories, between action and representation, between act and feeling, between science and conscience, and above. all between the instrument and the human body. All these "gaps" correspond to one similar structure, that of the advance or retard of one human faculty over another, just like the ideological theory is late in comparison to realities, just like representation is late in comparison to action.

For Anders, the cardinal illustration of the "Promethean gap" was that although the human kind was capable of manufacturing the Hydrogen bomb the human mind still could not fully grasp the far-reaching the consequences of the use of atomic devices some seventy years after the atom bomb was used for the first time, although optimists would point out that refraining from using an atom bomb on the battlefield for such a period could perhaps be interpreted as a sign of maturity in international relations. In much the same way, human feelings always seem to follow human action with a delay. Anders also pointed out that although military operatives had been capable of annihilating hundreds of thousands of people with blockbusters during World War II, those who perished in those bombings were neither mourned as individuals nor did they inspire repentance. As a matter of fact, GuntherAnders, whose real name was GuntherStern, held that the "obsolescence of Man" dated back from the conjunction of two major events in the context of World War II, the dropping of the first operational nuclear bombs over Hiroshima and Nagasaki in Asia on the one hand and the Holocaust of the Jews and the Rom in Europe on the other hand. Then, according to Anders all references to "humanism" became obsolete after those dramatic events, because they tragically revealed the distance between the very idea of Man and sacredness of the human body on the one hand and the ideology of the self-sufficient elites who had driven technological progress ahead of the rest of the human kind on the other hand. [6]

The "Promethean gap" is at the core of what GuntherAnders is called "the obsolescence of Man". Some sixty years after Anders, followed by a few others like Guy Debord or Enzo Traverso, bore witness to the fundamental changes that made "humanism" "obsolete" in all the walks of human life, one is struck by the pertinence of his analysis in the "digital society." The fact is that since the accomplishment of second industrial revolution, the individual has been ruled over by an elitist logics placing technology as the ontological end of humanity, leading to a dehumanizing of daily life, to a generalized commoditization of resources and services, and to the deregulation of the natural order of the world. In other words, through the production of evermore innovative products in the "digital society," the "creative class" has persistently accentuated the construction of a globalized world that the human kind cannot walk in step with. It may be a world that is beyond our current means of "understanding," of "comprehending," of "imagining," because it is beyond what our human emotions and responsibility can grasp. Hence, comes the question 
of "transhumanism." Since there is no formal limit to human production, Man himself is also a more or less finished morphological type, meaning more or less limited in his adaptive capabilities. It follows that Man cannot be remodeled as such, of his own volition or under the pressure of external forces. The challenge of human "obsolescence" comes from the fact that the adaptive elasticity of Man cannot be stressed ad libitum. Man may be "enhanced" or Man may work in interface with machines, but in that context he will necessarily cease to be human at some point [7]. The core of the problem is that Man has to live with the limitations of his own performances compared to the efficiency of the instruments that he has produced and that are able to self-improve in the process of his own reproduction. Besides, in the context of Schumpeterian innovation as an engine of growth through consumption, the collective psyche is being transformed by the new products on the markets, which might be characterized by a contradictory mixture of planned "technical obsolescence" and "digital perfection".

\subsection{The "march of the robots" v. human labor: from the instrumentation of the human body by chain work in the Fordian and Taylorian eras to working with "collaborative robots" in the "digital society." From the transformation of raw materials to editing things}

BMW, the German car company, brought its first "cobot" into use in its plant in Spartanburg, South Carolina in 2013. "Cobot" numbers have been growing rapidly since. In the vehicle industry "cobots" are expected to rise by more than $40 \%$ a year over the next five years, according to Research and Markets, an international research company. The "cobots," the collaborative robots, are changing the nature of the workforce in the manufacturing industry. They are not meant to replace purely and simply human beings in the production line, but to perform repetitive gestures with dexterity. Thus, "cobots" operate in an environment which is dominated by the thoughts, the mode of communication and the security of the human agents that labor alongside them. Rethink Robotics, a Boston robotics firm, had these objectives in mind when it revisited the concepts of robotics to develop two types of collaborative "cobots", a one-armed "cobot" named Sawyer, and another a two-armed one named Baxter. These two injection plastic-molded "cobots" developed by the American firm Tuthill Plastics Group in Florida, incorporate cameras and touch sensors as well as a screen that displays cartoon-like human facial features. Researchers at the Massachusetts Institute of Technology (MIT) have managed to improve non-verbal conveyance of human intention so that "cobots" are now able to decipher human brain signals. Researcher Daniela Rus and her team at the MIT have equipped an experimental version of a Baxter-model "cobot" with an electro-encephalography (EEG) decoding system that can recognize the human brain's signals of error-related potentials, thanks to a set of electrodes attached to a human "colleague" 's scalp. Such signals are generated by a human brain when it is making a mistake, and also when it is observing a mistake being made by another person. Indeed, the MIT researchers hope that in the future a Baxter-type "cobot" integrated in a team of human workers would be capable of logging an error made by a human "colleague" such as sorting an item into an incorrect bin for instance and fix that human mistake. And conversely, Dr. Rus and her team also hope that in the future a "cobot" that would have made a mistake observed by a human "colleague," would also be able to recognize the human brains signals emitted by that "colleague." Since asking the flesh-and-blood members of a human-"cobots" team to wear EEG caps at work would probably be too much of an intrusive practice to be acceptable to human workers, other research groups at the MIT are working on other ways to bridge the communication gap between humans and "cobots," such as speech or the recognition of facial expressions. Once a channel of communication has been established between humans and "cobots," what really matters is that "cobots" understand the right moments to convey messages to their "fellow" human workers and also how much information to convey. By all means, when attempting to convey a message to a human being, a robot must estimate its interlocutor's intentions and what his response is likely to be. Thus, algorithms designers must take into account what information the human "team mate" of a "cobot" already possesses, since too much information emitted by the robot might simply result in flesh-and-blood workers ignoring messages completely.

In the past, factory robots had been carefully separated from human workers for security reasons. The use of "cobots" within human production teams means that this separation has become obsolete, which does not mean that new security problems have to be solved. In their very design, "cobots" have been bridled in the power and the force that they can apply and stop moving instantly if they represent a danger for human workers. Dr. Julie Shah and her team's 
idea at MIT isto prevent dangerous contacts between flesh-and-blood workers and "cobots." To this end, researchers at the MIT have studied the human movements of shoulder and elbow or the swing of the torso so as to avoid accidental collisions with robots built in soft materials such as plastics so as to improve the machine's dexterity as well as the potential. danger it may represent. [8]

\subsection{The "march of the robots" v. human unemployment: from the reduction of production costs} to the mythical "end of work" predicted by Jeremy Rifkin and the discussions over "universal allowances"

As Mark Weiser, a chief scientist at Xerox's Palo Alto Research Center in the 1990s, put it: "The most profound technologies are those that disappear. They weave themselves into the fabric of everyday life until they are indistinguishable from it. " This is likely to be the case once again with the digital generation and robots:

Robots are better than humans at crunching numbers, lifting heavy objects, and, in certain contexts, moving with precision. Humans are better than robots at abstraction, generalization, and creative thinking, thanks to their ability to reason, draw from prior experience, and imagine. By working together robots and humans can augment and complement each other's skills. [9]

In his days, John Maynard Keynes (1883-1946) optimistically noted that technological innovation had always delivered more, not less, employment in the long run. However, Keynes pointed to the short-term dangers of a "new disease": "technological unemployment ... due to our discovery of means of economizing the use of labor outrunning the pace at which we can find new uses for labor." [10], the majority of economists seem to share Keynes's optimism on continued human employment despite automation. By raising productivity, automation, which economizes on the use of labor, will eventually increase incomes, their argument runs. In turn, that will generate demand for new products and services, which again will create new jobs for displaced workers. Industrialization, they point out, did not eliminate the need for human workers. This optimistic argument is usually completed with the demonstration that global wealth has always increased with innovation.

Conversely, the Nobel Prize-winning economist Wassily Leontief (1906-1999) in 1973, wondered in his book The future impact of automation on workers [11] whether human labor would go the way of horses, pointing out that although for many decades horse labor, which appeared impervious to technological change, was eventually doomed, once the right technology came along. Leontief went on, predicting that: "The role of humans as the most important factor of production is bound to diminish in the same way that the role of horses ... was diminished and then eliminated." In other words, Leontief raised the possibility that technological advance could sever the link that Alfred Marshall (1842-1924) had exposed in his seminal 1890 book, Principles of Economics [12], between infinite human wants and desires and full employment. Thus, according to Leontief, technological progress could be capable of decoupling ever-growing consumption and large-scale human employment, just as it did with equine employment.

For his part, economic historian Joel Mokyr [13], at Northwestern University in Illinois, points out, the more intricate machines, techniques and supply chains became, the more rewarded the workers who were capable of tending this new organization. On the one hand, employment grew for highly skilled workers, whereas unskilled workers, who had turned into cogs in the larger industrial process, and craft workers lost out. It was not until after World War II that workers in the rich world secured real prosperity, and that a large, property owning middle class came to dominate politics. And even so, the communist ideology, which can be partly seen as a legacy of industrialization's harsh early era, as well as the effects of the imperialism driven by European industrialization continued to be felt by millions throughout the world. More recently, Claudia Goldin and Lawrence Katz of Harvard University have shown in their book The Race between Education and Technology [14], that workers in the United States eventually won "the race between education and technology" in the early 20th century. Indeed, education in America generated massive economic expansion and rising standards of living. Throughout the 20th century, Godin and Katz point out technological changes increased the relative demand for skilled labor, while the rapid expansion of first high schools and then high education simultaneously increased the relative supply of skilled labor. 
Economic history teaches that the impacts of technological change take time before appearing, and that they vary highly from industry to industry, because change does not affect all workers in the same way. Some find that their skills are complementary to new technologies. Others find themselves out of work. In-between, while "general purpose technologies" [15] spread across the various sectors of the economy before producing what French economist Nicolas Bouzou calls the "creative synthesis," [16] the social fabric of society is strained and distorted before the benefits of innovation can be felt much, which explains why segments of the middle-class [17] are suffering after the rout of the angry working class at the beginning of the 21 st century.

Today's demise of production-line jobs and some sorts of bookkeeping, lost to the robot and the spreadsheet. The truth of the matter is that innovation wipes out some jobs and changes others, in the process of Schumpeterian creative destruction. Automation is now beginning to have the same effect on white-collar jobs as it already has on blue-collar ones. Michael A. Osborne [18], a machine-learning expert at Oxford University, who had examined learning through the life course under its social, economic dimensions in lifelong learning and schools, in formal post-compulsory education, at work, at home, in the community and the region thanks to information and communication technology, joined forces with Carl Benedikt Frey, another Oxford academic, to produce in 2013 a report entitled The Future of Employment: How susceptible are Jobs to Computerization?.

We examine how susceptible jobs are to computerization. To assess this, we begin by implementing a novel methodology to estimate the probability of computerization for 702 detailed occupations, using a Gaussian process classifier. Based on these estimates, we examine expected impacts of future computerization on US labor market outcomes, with the primary objective of analyzing the number of jobs at risk and the relationship between an occupation's probability of computerization, wages and educational attainment. According to our estimates, about 47 percent of total US employment is at risk. We further provide evidence that wages and educational attainment exhibit a strong negative relationship with an occupation's probability of computerization. [19]

\subsection{Retraining the workforce through lifelong learning in the "Knowledge society"}

Commentator Andrew Sheng in The China Post was disappointed out in 2016, that "... the only Tech Age solution is proper education and training on the job ... (since) governments cannot assume that the market will provide the jobs without state help ... (and that conversely), employers need to be aware that you can't shed labor without investing in people. "And the commentary continued: "Increasingly, societies are networks across which goods, services, information and value are traded, exchanged and created. Those who have access to these networks grow wealthier, outstripping those who are not. " [20]

Arthur Cecil Pigou (1877-1959), a British economist influenced by John Maynard Keynes, Alfred Marshall and Karl Marx, [21] is credited with coining the term "human capital." The notion of "human capital" refers to the abilities and qualities of people that make them productive. Knowledge is the most important of these, but other factors, from a sense of punctuality to the state of someone's health, also matter. Thus, investment in human capital mainly refers to education but is also about other things, such as the inclusion of values by parents or a healthy diet. [22]

Furthermore, the formation of human capital has also something to do with culture. Gary Stanley Becker (1930-2014) who produced a full-fledged theory of human capital, [23] used to point out that Asian economies with few natural resources such as Taiwan's or South Korea's had been able to develop thanks to the human capital of their populations. Generally speaking, the hard-working Prussians of yore or Chinese in these days of globalization, Protestant ethics-inspired entrepreneurs in Puritan America [24], or rested, well-fed workers in today 's poor countries make the difference in terms of human capital. It is clear that human capital plays a crucial role in terms of innovation-driven economies and that cultural traits matter. Thus, the emergence of Chinese entrepreneurs by the end of the second decade of the 21 st century is likely to have a powerful impact on industries and consumers worldwide, [25] just as the Silicon Valley high tech innovators have had for three decades in America. In the context of globalization, innovative human capital is a prerequisite to being able to use world-class technologies from supercomputers to gene editing, cloud computing, sensing technologies, or artificial intelligence paving the road to autonomous driving. 
As far back as Adam Smith (1723-1790) [26] in the 18th century, economists have noted that production depended not just on equipmentor land but on people's abilities. For a company, investing in human capital is paid off just as investing in physical capital. Besides, investment in human capital also paid off for people since the earnings of well-educated individuals were generally higher than those of the wider population. Refining the concept of human capital under the influence of Milton Friedman at the University of Chicago in the 1950s, Gary Becker made humans the central focus of economics. Becker noted that companies were ready to pay for "specific human capital," which arose when workers acquired un-transferable knowledge directly tied to their firm, such as how to use proprietary software for instance. By contrast, as Pigou had suggested, firms were reluctant to stump up the "general human capital," such as teaching employees to be good software programmers for instance. Employers would not want to teach skills to employees only to see them poached by rivals. Companies today are more likely to arrange online communities of learning" on their intranet to help their employees enhance their skills within their organization rather than finance for them expensive MBAs that would set them free. For his part, Becker observed that people generally acquire "general human capital" at their own expense, rather than at that of their employers. University students take on debts before entering the workforce and almost all industries train interns, trainees or junior employees, who share in the cost of acquiring knowledge by being paid less.

Although Becker was criticized for exaggerating the purposefulness and rationality of employees' decisions to further their education, lifelong learners have always tended to compare expected future earnings from different career choices and considered the cost of acquiring the education to pursue their careers, including the time spent in the classrooms. Thus, by the end of the second decade of the 21st century, MOOCs have started to play a crucial role in the education of human capital, worldwide, in the "digital society." Becker's full-fledged theory on human capital was based on an "economic way of looking at life." Becker [27] pointed out that longer life expectancy raised the profitability of acquiring knowledge in younger generations. He noted that advances in technology made it more profitable to have skills, which raised the demand for education. Finally Becker's theory "suggested that there was no fixed number of good jobs but that highly paid work would increase as economies produced more skilled graduates who generated more innovation." Becker [28] highlighted himself that one quarter of the rise in per person incomes from 1929 to 1982 in America was generated by increases in schooling.

With the technological advances in the 21st century, the knowledge that people acquire in school is becoming more quickly obsolete more quickly than before. At the same time, longer life expectancy means that the returns on mid-career training are higher than in the past. Obviously, the replenishing of human capital depends on lifelong learning. Besides, the educators of today have to figure out what the employees of tomorrow will need by 2070 , asking themselves what the challenge of Artificial Intelligence will be to the Human Intelligence of the workforce by then:

On the one hand, AI is progressing faster than anyone predicted. Each year the learning speed of AI is multiplied by 100. On the other, we have schools that haven't evolved in 250 years that are preparing our youth for careers that won't exist in the near future. Few curriculums have integrated programs on AI. What impact will this have on the job market? How can we make sure our biological brains remain complimentary to AI and are not engulfed by it? How will our children be able to remain competitive with AI?. [29]

\section{The "Promethean gap" and The New Realities of Trade in The "Digital Society"}

\subsection{The on-line connectedness of customers and Internet users in the "digital society"}

Another aspect of the "Promethean gap" manifests itself in the new realities of trade in the "digital society." The on-line connectedness of customers in the "information society" boils down to the fact that through Internet navigation potential customers know more about the products they are looking for, than the salesman who used to sell them to them in the somewhat outdated "brick and mortar" structures. Conversely the Marketing target of sellers is to obtain the shortening of the customers' buying decision process. The supply side's targeted data mining of potential customers through algorithms is efficient enough to push the latter's impulsive on-line buying. 
As a matter of fact, with the contemporary, economic use of the big data, which turns the homo economicus into another instrumental resource, the economic activity has moved from the "real" world to the "virtual" world. Furthermore, the agents of the manufacturing industry and services now turn towards artificial intelligence and algorithms which decipher the wants of consumers even before the latter are aware of them. Algorithms are everywhere: they play most of the stock market, they decide whether people deserve a mortgage or not and may one day drive a driverless car for them. Essentially, algorithms are sets of precise steps that need no great mental effort to follow but which, if obeyed exactly and mechanically, will lead to some desirable outcome. Thus, they are ideal for performing tasks which humans generally find frustrating or alienating [30].

The tentacles of giant digital squids like Amazon, Facebook or Google that have become "monopolies" by the definition of Franklin Foer, encircle both public and personal life and bruise democracy as they serve up information based on opaque algorithms, suggesting what people should think, and so supplanting individual thought. [31] The "existential threat" from a few "dominant firms with pernicious powers," which merely compete "on the fringes of empire" exert so much power that people demur from criticizing them. In practice, a tech giant like Google has not refrained from suppressing rival comparison shopping sites or like Facebook from selling political advertising to a foreign power on its site during the 2016 American presidential election. A number of analysts have already called for regulators to exert closer scrutiny on those somewhat opaque tech giants and the European Commission has fined Google a record-breaking \$2.7bn for its illegal practices in June 2017.

Like every other deep change, the "digital revolution" calls for a reassessment of the idea of "obsolescence" in every walk of life as well as in the ideological "constructs" that glue societies together. Like the first and the second industrial revolutions, the "digital revolution" is progressively turning the human body into something of a somewhat obsolete, productive agent. By the end of the second decade of the 21stcentury, human consummation has been geared by the "consuming society" onto the planned "technical obsolescence" of products, which are constantly being renewed for the sake of Schumpeterian innovation as an engine of economic growth. In a broader sense, the digitization of production and society has been surreptitiously transforming the control of governments, the collective psyche and the individual "habits of the heart," which were inherited from the previous stages of human development. Besides, as German philosopher Heidegger has noted, each historical period in the development of philosophy has corresponded to a temporal need of its own [32].

In 2017, Jonathan Taplinhas traced the destructive "monopolization of the Internet" by Facebook, Google and Amazon, a process which has cornered culture and changed the functioning of democracy in the West, besides changing the lives and status of musicians, journalists, authors and filmmakers in the "digital age." Taplin has shown how Facebook, Google and Amazon have shaped online life by tolerating the piracy of books, music and film while at the same time promoting opaque business practices and subordinating the privacy of individual users, so that by the end of the second decade of the 21stcentury the latter have come to live in a surveillance marketing monoculture. Indeed, since 2001, newspaper and music revenues have fallen by $70 \%$, book publishing, film and television profits have also fallen dramatically. Revenues at Google in this same period grew from $\$ 400$ million to $\$ 74.5$ Billion. Google's YouTube today controls $60 \%$ of the streaming audio business and pays only $11 \%$ of the streaming audio revenues. More creative content is being consumed than ever before, but less revenue is actually flowing to creators and owners of the content [33].

\subsection{From "Attention Harvesting" to "Virtual Reality" Marketing}

Anders's analysis of the consequences of the second industrial revolution on the human "soul" in the 1950s run deeper and wider than the mere grasping by contemporary governments and workers of the disruption of the post-industrial labor patterns with the advent of digital technology in the 21 st century. The illusions of a "borderless world" within the framework of economic globalization and the ubiquitous use of the Internet were relatively short-lived. Globalization quickly met governmental coercion [34]. Columbia University Media Law Professor Tim Wuhad coined the phrase "net neutrality" in 2003 and laid down its principle. Tim Wu conceived "net neutrality" as an extension of the long-standing concept of "common carrier," which was used to describe the role of telephone systems. The principle of "net neutrality" was that Internet service providers and governments regulating the Internet 
had to treat all data on the Internet the same, and not discriminate or charge differently by user, content, website, platform, application, type of attached equipment, or method of communication. Then, in 2010, Tim Wu showed that the patterns of the 20th century media radio, telephone, television and film were repeating themselves in the 21 st century as a continuation of sorts of history of the "mass production of the spirit" in the "digital age." Each of the media of the 20th century was born free and open, and each invited at the beginning unrestricted use and entrepreneurial experiment until some mogul imposed total domination [35]. In 2016, Tim Wu examined in depth the rise of "attention harvesting," and its transformative effect on the digital society "and what Anders called the human " soul "in the 1950s [36]. Invention begets industry and industry begets empire, a state of things that governments quickly take advantage of as the maneuvers of the great information powers in the "digital age" show.

By the end of the second decade of the 21st century, "virtual reality," that is the immersion of an individual in a 3-dimension virtual environment, is transforming the very perception of that individual through its cerebral system. Thus for instance, the brains of an individual who acquires the virtual usage of a sixth finger integrates a new sensorial dimension so much so that the latter feels missing for some time after that individual comes back to the real world and the use of a five- fingers hand. Deprived of instruments like a computer mouse or keyboard, the individual who moves about in a virtual tri-dimensional world will probably be able to interact one day with his virtual environment only thanks to his own electro-cerebral waves.

\subsection{The "Promethean gap" and the "myth of cyber security": learning to live with computers that will never be secure and the limits of encryption in digital exchanges}

At the end of the second decade of the 21 st century, one may think that computers will never be completely secure. On the contrary, the computerized extortion of digital goods might get worse in the future. Indeed, computers nowadays do not only contain abstract data from the virtual world such as the confidential details of a credit-card or massive databases, but also increasingly data from the real world, such as information that deals with physical objects and vulnerable human bodies.

At the end of the second decade of the 21st century, cars with drivers or self-driving cars have become computers on wheels, and airplanes computers with wings. Furthermore, with the arrival of the "Internet of Things," computers are baked into everything from road signals and medical scanners to insulin pumps and electricity meters or children's toys. And hackers have already proved that they could take remote control of connected cars or pacemakers.

At the end of the second decade of the 21 st century, there is no way to make computers completely safe. Indeed, software is a hugely complex system to design. Thus, Google for instance, must manage around $2 \mathrm{bn}$ lines of source code, which means that errors are inevitable. The average programmed software has 14 separate vulnerabilities, each of them representing a potential point of illicit entry into the system. Such weaknesses are historically compounded by the initial development of the Internet network, in which security was originally an afterthought. In addition, the innovation culture that ensured the preeminence of the Silicon Valley over all the other high technology regions in the United States consisted from the start in putting new products on the market although they still needed perfecting, especially in terms of security.

At the end of the second decade of the 21stcentury, hacking has developed on all sorts of targets, from botnets to networks of computers and from desktop computers to routers and "smart" light bulbs. The malware infected computers and attacks seriously raise the question of the designers' liability. If the definition of the manufacturers' liability is extended, one may think that in the future the firms affected by such an extension will immediately send their fixes to their products through their connected gizmos as soon as flaws are found. Lawmakers Could force computer firms to be responsible for the harm caused to their products when they go wrong because of cyber-attacks by imposing a legal liability: firms would be held liable for the security of their products in the course of time when confronted with hacking. Legislators would also impose an insurance system on manufacturers to guarantee the security of their computer products. These two types of measures would force the emergence of safer behavior among software makers out of respect for the users of their products. As a matter of fact, software companies would be obliged to disclose the fact that they or their products have been hacked instead of hiding it, as is already the case in some American states. Lawmakers could also demand that users change default usernames and passwords after an attack.

Many computer-security experts compare the current software manufacturers' disclaiming of liability to that the American carmakers in the 1960s, as least until Ralph Nader published his best selling book "Unsafe at Any Speed" 
in which he exposed and excoriated the lax attitude of car manufacturers in terms of security. Indeed, the American legislator had reacted in the year following the publication to impose security rules on American carmakers, starting with compulsory seatbelts on seats.

In the computer industry sector these days, the insurance market of firms specializing in cyber-security is still young but it is rapidly growing, at least fast enough to protect consumers on the one hand and preserve the creative risk-taking of the computer industry to innovate on the other hand. By the way, this nascent insurance market in the computer industry could negotiate the first carve-outs from the manufacturers' liability for their products' security in the course of time.

Thus, one may think that it would be the economic tools, and not only the technical tools that would allow an evolution of the attitudes and behavior of the computers' manufacturers and the users of their products confronted with the large and growing number of bugs and hacking. After all, the governments' priority is to refrain from making situations worse, which implies choices from the states. Thus confronted with terrorism, governments have chosen not to weaken encryption because it is in the general interest that the encryption system be strong to preserve the confidentiality of data and the security of transactions, be it at the cost of making it more difficult to intercept suspect exchanges on the web between potentially dangerous people. Conversely, facing the lack of expertise of computer users that hampers their abilities to protect themselves, it is legitimate that governments intervene to regulate the security of products, whether they are cars, computer software or smartphones [37].

\subsection{The "Promethean gap" and the commercial consequences of predictability in the "information society": the example of DNA reading and the insurance industry}

With the progress in genetics, genetic diseases are becoming more predictable and this new predictability is transforming the individuals' self-assessment of their own lives and the relationship between themselves and society, shifting the limits of what is socially acceptable. Obviously, this new situation is having an impact on risk management and particularly on the insurance industry. Both, genetic predictability and genetic engineering significantly alter individual health prognosis and access to individual medical data. This new state of things has a bearing on individual minds as well as on the collective psyche, as the case of the insurance sector illustrates. Diagnostic genetic tests used to be the exclusive matter of medical laboratories. By the end of the second decade of the 21 stcentury, predictive genetic tests could be ordered online for an affordable sum of money to a majority of people. In April 2017, one company in California, 23andMe received regulatory approval to screen for risk factors connected to ten diseases and genetic conditions, including late-onset Alzheimer's and Parkinson's. This piece of news was by no means anecdotal since predictive genetic tests unlike diagnostic genetic tests are conducted on people without symptoms. Thus, scientific advances are likely to significantly disrupt the insurance business.

Insurers fear that without equal access to the genetic information of their savvy customers, they might lose out to them. Conversely, consumer groups fear that "if underwriters did have access to such information, people with" bad "genes might find themselves unfairly excluded from cover". Because predictive genetic tests unlike diagnostic ones often need not be disclosed, the prospective customer can secure an advantage over a future insurer. Thus, a person learning that they might die young may want to buy life insurance. Or someone being informed that they may die of contract cancer may buy cancer or critical-illness cover. As a matter of fact, Robert Green, at Harvard University, found that people who were told that they tested positive to ApoE4, a mutation of a gene related to increased risk of Alzheimer's, were five times more likely to buy long-term care insurance than those without such information. Asymmetry of information with the customer knowing something relevant about their health is likely to ruin the insurance business if predictive tests further improve while non-disclosure rules stay in place. Conversely, tests might also help insurers. Thus, Swiss Re, a reinsurance giant, is most excited about tests that spot early signs of cancer or cardio-vascular disease. Indeed, such information could be invaluable to insurers. Discovery, a South African health insurer, plans to offer customers a test that maps part of their genome focusing on "actionable data", that is on the possibility of medical intervention or life-style change that could mitigate risk. Obviously, this might help people who are already insured. However, such policies worry customers that prospective underwriters might use predictive information to discriminate. Such a situation would boil down to losing access to insurance. 
Genetic discrimination is an ethical question indeed. Regulators today often protect consumers from mandatory disclosure of predictive tests. In several countries, however, life insurers may already ask for disclosure of predictive genetic tests for policies over a certain value. Apart from Huntington's chorea, where a test of one gene is infallible, most illnesses stem from a number of factors, including life-style and environment, and a combination of genes. Some regulators, such as Germany's have outlawed direct-to-consumer tests. Besides, one may assume that insurers will eventually have access to relevant genetic information. The question is what they will be allowed to do with it. "When blood tests for AIDS first appeared, many jurisdictions ruled that they could not be used for calculating health premiums, as these were a basic good, but could be used for life policies." One may assume that as genetic testing spreads are similar, difficult juridical assessments will have to be made [38].

\section{The "Promethean Gap" and The New Realities of "Human Body Engineering" in The "Digital Society"}

After the moral disasters linked to the use of the technological advances of the second industrial revolution - the Holocaust in Europe and the use of the atom bomb over Japan - GuntherAnders thought that a critical philosophical approach of the limitations of the human kind was an urgent priority. Anders did not call for another formal, theoretical discussion on the limits of human reason. For Anders, the core philosophical question in the post-industrial period was human limitation itself. Anders did not merely mean the limits of human Reason, which had been examined by philosophers in previous centuries, but he also meant the limits of all human faculties, such as human imagination, human feelings or the human sense of responsibility. Anders thought that the developments of philosophy in the post-industrial period had failed to address the fact that the limits of human production had literally exploded and that this called for a new philosophical inquiry into the limitations of the human kind. Furthermore, Anders deplored that the vague philosophical speculations on human finitude were not founded on considerations of human helplessness in the context of the second industrial revolution but almost exclusively on human mortality as a metaphysical sign of human finitude [39]. Way back in the 1950s, Anders had already noted that "human engineering" was accelerating the metamorphoses of the human soul, without metaphysically reflecting on human limitations [40]. Things have not changed much by the end of the second decade of the 21 st century.

By the end of the second decade of the 21st century, the "obsolescence of products" is a notion that escapes the freedom of individuals to decide. At the same time, innovation and the spectacular scientific progress in biotechnologies is setting new limits to human physiological "perfectibility." The physical and mental obsolescence of individuals, that is their aging, is receding with the lengthening of longevity, even if immortality remains an improbable objective. Besides, the conditions of death are improving although the end of human existence is not devoid of diseases and handicaps. In developed societies, the common man tends to live for longer, but in poorer health near the end of that prolonged lifespan. In Silicon Valley, Google invests considerable sums of money in the physiological "enhancement" of human beings through its subsidiary Calico, whose objective is to prolong human life onto a standard average age of 120 years.

The combination of the spectacular innovations in nanotechnologies, biotechnologies, computer sciences (the big data, connected objects) and cognitivism (artificial intelligence and robotics) has been raising considerable ethical, political, economic and spiritual speculations. Indeed, scientific progress has deepened human knowledge to the point that it is within reach of transforming human nature and the human kind. Liberal eugenics and the enhancement of human beings are on the agenda of transhumanism, pointing the way to improvement, and posthumanism, pointing to the ultimate objective to achieve, a new hybrid man-machine species, according to Ray Kurzweil and his apostles at the Google -funded University of Singularity in California. In July 2015, the scientific community petitioned against the excessive use of cognitive technology. Bill Gates (Microsoft), Stephen Hawking (physics theoretician and cosmologist working for NASA), Elon Musk, (co-founder of the association on artificial intelligence and better known for being the boss of Tesla Motors that produces driverless vehicles), among another thousand scientists, warned their peers of the danger of an artificial intelligence that would become "strong." They meant by that, that artificial intelligence would have absorbed the whole of human knowledge including that part that would have been designed in order to disconnect machines in case they would be tempted to escape human control. 
4.1. The transhumanist project and the "obsolescence" of the human body in the "digital society": pushing the limits of human finitude and death, from "curing" to "enhancing" through gene manipulation

The transhumanist project, which pervades innovative minds in the Silicon Valley and some of the orientations of the GAFA (Google, Apple, Facebook, Amazon) and other majors of the Internet-related industry, like Microsoft, Twitter or LinkedIn, has been theorized in the past decade.

The first occurrence of the word "transhumanism" is to be found in the works of Sir Julian Sorell Huxley, (1887-1975) a Socialist and progressive, British biologist known for his books of vulgarization on biology and evolution. A proponent of eugenics as a way to improve the humankind, he was the grandson of Thomas Henry Huxley (1825-1895), who was a colleague and supporter of Charles Darwin (1809-1882), and the brother of writer Aldous Leonard Huxley (1894 -1963), who wrote the science-fiction novel Brave New World In 1932 [41]. Julian Huxley saw evolutionary biology as part of eugenics, [42] and supported in The Geneticists' Manifesto In 1939 the idea that "left-minded" eugenics would eventually result in an improvement of social conditions. As a matter of fact, eugenics and "ectogenesis" [43] a concept invented by John B. S. Haldane was in fashion among biologists and physicians in the 1930s [44]. Eugenics was seen as part of scientific progress [45]. According to Nicolas Le Dévédec, the growing interest for the transhumanist project in the western world at the beginning of the 21 st century, especially for the biological "enhancement" of human nature would be due to the decline of interest for the classical humanist Enlightenment project, which focused on social and political improvement by means of constitutional arrangements [46]. Trying to "enhance" human nature by means of genetic engineering brought back an interest for "ectogenesis" [47] as opposed to in vivo genetic manipulations.

Nick Bostrom and Julian Savulescu opened the debate on human "enhancement" ethics in 2003 [48]. The core of the matter hinged around the sacredness of human "nature" and the looming dangers of eugenics when "playing God" through genetic engineering [49]. Figuring out human "enhancement" in ethical terms was difficult from the onset [50], well-nigh impossible when set in social terms [51]. In 2003, for most participants in the American ethics commission, any selection of human beings either by society or by the parents of embryos yet to be conceived echoed too much of Nazi eugenics, or of the manipulation of sports for political purposes in totalitarian regimes [ 52] and clearly precluded the possibility of anapproach in the light of a liberal, regulated, biological enhancement of human life. Yet, they concluded to an obligation of pursuing and participating in research and to distinguish the good from bad uses of technology.

The biological enhancement of the human body leads to a number of questions: What enhancements are available and why they matter? Does improving the conditions of senescence mean that "immortality" will be available? In what way can reproductive choices be compatible with the democratic presumption in western-style democracies? Is biological "enhancement" about offsetting the effects of disability or acquiring "super-ability"? Is the quest for genetic perfection a viable project for mankind? Can the use of the embryo as material for research and genetic "enhancement" be regulated? Has humankind a future beyond genetic "enhancement" ?.

According to French philosopher Luc Ferry, the current transhumanist project in the 21st century is heir to three major influences: 1) a certain stream of classical humanism, 2) an optimistic and technophile scientist current that developed from Modern times with the Enlightenment and the scientific revolution to the advent of NBICs, robotics and artificial intelligence, 3) science-fiction literature and culture, 4) the counterculture of the Sixties featuring all the features coming from Jacques Derrida's deconstruction efforts, namely, feminism, ecology, egalitarianism and libertarianism that lead to the American concept of "political correctness." [53]

One current of the classical Enlightenment humanism, which went along with human rights and democracy, insisted on the infinite perfectibility of human beings. From Pic de la Mirandole to Condorcet and Kant, by way of Rousseau, Francis Bacon, Fergusson or de La Mettrie, human beings have not been considered as originally embedded once and for all in an intangible and determine human nature that would have made the humankind inseparable from the shell of its natural instincts. This classical humanist tradition supporting the idea of an "infinite perfectibility" of 
humankind is represented by some passages of Condorcet in which the author clearly states that nature has set no limits to the possible "enhancement" of intellectual, moral and physical human faculties [54]. Echoing Rousseau's idea of the "perfectibility" of human nature, progress can be accomplished not only in the organizational field of society and politics, but also in improvement of human nature itself.

From times immemorial the principle of "therapy" had been to "repair" the "impaired" being. In ancient Greece, the doctor was meant to restore the biological harmony of the human body, just as the judge was meant to restore the harmony of the social body. Curing diseases in the human body or remedying evils in society boiled down to restoring order in both cases either by eradicating pathogens with medicine or crime with the rule of law. However, with the NBICs and the advent of the "collaborative economy," the purpose of physiological and social care is de facto no longer limited to curing the body and society but potentially extends to "enhancing" the human body and improving the social body. Thus, the transhumanist literature points out at great length to the gradual blurring of the frontier that used to separate therapy from "enhancement" or "improvement" in recent years. Indeed, the existing recourse to plastic or cosmetic surgery, the medical treatments to fight the effects of senescence or the shortcomings of impotence with Viagra, among others, could not honestly be labeled as "therapy." Besides, allowing a blind person suffering from a degenerative disease [55] to recover sight thanks to the implant of a chip on their retina turns such a person into a man / machine hybrid of sorts.

It develops the idea of human perfectibility if not perfection and of human biological "enhancement". In a way, its aims at "making humans more human," thanks to converging NBIC technologies and the exponential development of the so-called "collaborative economy," with the restriction that the later may lead to a commercialization of the world that could potentially yield considerable profits in the future by means of deregulation. This first approach to transhumanism opposes the proponents of "bioconservatism" to the proponents of "progressivism". Human "enhancement" is progressively becoming available in two spheres: the "somatic sphere" and the "cognitive sphere." [56] It also encompasses the human "identity" and the prolongation of human life "beyond death." [57] The human dream of "immortality," or the "endless life" that the King of Uruk wanted to conquer, have existed since The epic of Gilgamesh [58] that was composed some 18 century B.C. In addition, immortality has been a central theme of monotheistic religions and Buddhism through successive reincarnations. Yet, it has taken a new turn and a new meaning with the new converging NBIC technologies in the 21 st century. Aging, senescence and longer life spans can potentially be considerably improved [59] thanks to hybridization and reparative medicine [60] in the not so distant future. Death would still exist but it would be caused mainly by accidents, bombings, wars or suicides. Human "enhancement" has also to do with human intelligence and "enhanced" decision-making. [61] It obviously calls for biopolitics, policy [62] and regulation. In the wake of classical humanism, the biological transhumanists, who want to "enhance" human beings and improve human beings, favor an ethical approach in order to draw the limits of their project especially when it comes to the possibility of an irreversible manipulation that would alter nature.

\subsection{The post-humanist project and the "obsolescence" of human intelligence in the face of} artificial intelligence in the "digital society": from self-enhancement to externalization through the man-machine interface

The philosophical core idea of the transhumanist project is to be found in materialism, behaviorism and utilitarianism, which are classic features of Anglo-Saxon philosophies. The keystone of its philosophical architecture is to step "from chance to choice," [63] from fate to human freedom, from genetic lottery to freely consented "enhancement." The goal is to liberate the individual from all sorts of constraints and alienations imposed but brute nature or the arbitrary traditional nature of existing social, political and economic organizations. The transhumanist project can be divided into two main approaches. The first approach to transhumanism is a prolongation of sorts of the classical humanism of the Enlightenment in the 18th century. The second approach to transhumanism pleads for a "posthumanist" or "anti humanist" project aiming at the creation of a new hybrid species capable of externalizing its knowledge, and thus becoming a thousand times smarter than the old humankind. Those hybrids would also be capable of self-learning, repairing themselves, learning from their mistakes, and perhaps of being capable of feelings. The biological "enhancement" approach aiming at making "humans more human" and the cybernetic approach of 
"singularity" are nor as antagonistic as they seem. According to Pramod K. Nayar posthumanism's roots can be traced in disability studies, animal studies and bioethics to underscore the constructed nature of "normalcy" in bodies, and the singularity of species and life itself [64]. In a way, "transhumanism" is the itinerary, "posthumanism" is the goal.

The second "posthumanist" approach is represented by the unsettling [65] "cybernetic" project of a systematic man / machine hybridization relying more on robotics and artificial intelligence than on biology. Its figurehead is Ray Kurzweil [66], the boss of the Singularity University, which is financed by Google. The ultimate goal is to create an entire new species, a being interfaced with a computer, connected with the information contained in the entire Internet resources thanks to brain implants, some creature a thousand times smarter than the humankind [67], the ultimate mutant of Lucypresented at the end of the eponym movie that Luc Besson shot in Taiwan in 2013. This second form of transhumanism is based on the concept that machines equipped with "strong" artificial intelligence could soon overtake the intelligence of biological humans. In that respect computers equipped with "strong" artificial intelligence have already outwitted the world champions on the chessboards and at the strategy game of go, without speaking of Watson the IBM computer that outscored its human competitors in the famous American TV game Jeopardy! This project conceived on the materialistic premise that the human brain is just another complex material structure that can be duplicated and "improved" thanks to artificial intelligence and robotics is based on the belief that the sphere of intelligence and the sphere of emotions can be separated, just like a computer hard-drive and a USB key. Those robots would not only be capable of imitating human intelligence they would also be self-conscious, somewhat emotional, autonomous and in some ways almost immortal.

The "posthumanist" project, as wild as it may look reminds us that the existing worldwide Web, big data and social networks already look likeyet another externalization of the human body. Indeed, they function like an extension of the nervous system that simultaneously irrigates the virtual and the real worlds. In some ways, the new ubiquitous connectedness means that people go about their daily lives carrying their heads around in the form of a mobile telephone or an i-pad a "well-made" and a "well-filled" head at that; Pramod K. Nayar, "posthumanism" criticizes traditional humanism on the ground that it is exclusionary and "speciesist" that is positions the human as a distinctive and dominant life form. Then, Nayar "contextualizes the posthumanist vision which, drawing upon biomedical, engineering and techno-scientific studies, concludes that human consciousness is shaped by its co-evolution with other life forms, and our human form inescapably influenced by tools and technology." For Nayar, "posthumanism" marks a radical reassessment of the human "as constituted by symbiosis, assimilation, difference and dependence upon and with other species." [68]

\subsection{The "Promethean gap" and the "obsolescence" of the human body in the "virtual world": new human perceptions and interactions from "avatars" to 3-dimensions "virtual reality"}

"Digital natives" have indeed a different relation to time and space than their predecessors. With permanent connectedness, the immediacy of exchanges, the choice between multiple media and the variety of exchanged contents, they have come to redefine their relationships with other people. The time necessary to have access to information being short for them, even shorter with multitask application tools, "digital natives" hate inactivity and slack periods, so that they will fill those gaps with digital hyperactivity. Besides, their perception of space has been altered by their standardized, digital environment at home, and by keeping updated on their favorite, global, brand names, media and television series that make them feel at home wherever they travel in the real world. Furthermore, they are confident that global news networks will keep them posted with any change that might happen anywhere in the world. "Digital natives" are constantly gambling, and the game theory pervades almost everything they do. They are in the habit of using trickery, resorting to "great ideas", and trying to outsmart salespeople in shops, or their co-workers and their hierarchy at work. Because they are used to zapping quickly online from one item to the next with their digital tools in cyberspace when they are up against a problem to solve, likewise, they will try to get round obstacles in real life. Thus, they will try to avoid confrontation and assume as Google does that there is a solution to every problem. Yet, this assumption may lead "digital natives" to make radical decisions in their real lives, such as quitting a job that they dislike, or finding some trick to procure goods that they cannot really afford. 
The "digital natives" 'use of digital tools has a distinct impact on their ways of learning. The short time needed to get access to information breeds general impatience in them. Furthermore, the use of multitask applications, which combine a simultaneous use of phones, laptops, desktops, television screens, computers or overhead projectors, produces a difficulty in concentration when it comes to acquiring knowledge not just getting information. Furthermore, "digital natives" feel an urge to frequently change activities to prevent weariness. In addition, the sensorial dimension of digital resources will entice "digital natives" to select practical, illustrated data both in terms of content and form. Hence, when it comes to their own education, a subgroup of the "digital natives" will tend to prefer short-term vocational, practical training over long-term, abstract, academic studies a preference that still has very much to do with the education received at home in the real world as Pierre Bourdieu evidenced in the pre-digital era.

\subsection{The "Promethean gap" and the possibility of "editing humanity": the promises of the new technique for manipulating genes $\mathrm{v}$. the realities of governing human reproduction}

In April 2015, a team of Chinese geneticists started an experiment on 83 human embryos in order to repair or enhance the genome of their cells. They used the R technology to edit the genome of those human embryos that were not meant to develop to term in the first place. Indeed, earlier on, French researcher Emmanuelle Charpentier and American researcher Jennifer Douna had figured out a technology known as CRISPR-Cas9, or just CRISP. CRISPR-Cas9 is a powerful gene-editing technique, which is altering the genetic material of living organisms. It involves a piece of RNA, a chemical messenger designed to target a section of DNA, and an enzyme, called a nuclease, that can snip unwanted genes out and paste new ones in. Thus, with authentic simplicity, speed and precision, it becomes possible to repair defective genes in the embryo. Scientists are now capable of routinely reading, studying and comparing DNA sequences for humans. This means that genetic engineering could correct terrible genetic defects that blight human lives. It also heralds the not-so-distant prospect for parents to design and build their customized offspring to order. Nevertheless, researchers can turn to CRISPR for a whole range of applications, such as developing therapies for everything from Alzheimer's to cancer to HIV. "By using doctors to put just the right cancer-hunting genes into a patient's immune system, the technology could lead to new approaches to oncology. It may also accelerate the progress of gene therapy where doctors put normal genes into the cells of people who suffer from genetic diseases such as Tay Sachs or cystic fibrosis." [69]

The Chinese geneticists' experiment, which edited the genomes of human embryos in April 2015, already raises the ethical question of engineering viable embryos one day for purely therapeutic reasons or even non-medical "enhancement." Scientists are now also capable of routinely reading, studying and comparing DNA sequences for other species as well. Malaria kills more than 400,000 people, mainly children, every year. Zika, another mosquito borne virus that appeared in Brazil in early 2015 had spread to more than 60 countries in the Americas, Africa, Asia and the Pacific islands by September 2016, and 2.6 billion people lived by then in areas where the deadly virus could spread according to the September 1stissue of the Lancet [70] So the reasoning goes that without mosquito species such as anopheles gambiae and Aedes aegypti, the world would be a better place. Thus, genetic engineers have already moved in that direction. For instance, male Aedes aegypti mosquitoes have been modified to become sterile and released in Brazil. So far, such practices, which have already been controversial, have been limited in their impact and geographical range. But things could change rapidly with the nascent technique of "gene drive" that almost guarantees the irreversible transmission of the gene modification to the offspring - instead of the conventional laws of inheritance that predict that offspring have only a $50 \%$ chance of inheriting a specific gene. The new gene-editing technology coupled with lavish funding the Bill and Melinda Gates Foundation said that it would increase its investment in gene drives to $\$ 75 \mathrm{~m}$ in August 2016 could open the way to the extirpation of entire species. If mosquitoes are the main targets because of malaria or the birth defects caused by Zika, ticks that carry Lyme disease, or bats that are reservoirs of infectious diseases, are also on the list of the pests that could be eliminated. But of course, as interest grows, so do the concerns. On the one hand, absolutists claim that it is morally wrong to take a deliberate decision to eliminate ant species. On the other hand, those who suffer from horrible 
diseases such as bilharzia or Guinea worm will tend to see the eradication of some infectious species as a major advance in public health, a much bigger victory than the eradication of smallpox in 1980.

In March 2017, researchers in China reported the first successful application of CRISPR-Cas9 to a disease-causing genetic mutation in human embryos. The results of that experiment were mixed. However, "a group of researchers from America, China and South Korea have pulled off a similar trick, with striking consistency, among many more embryos while avoiding several of the pitfalls of previous experiments." [71] One may assume that CRISPR-Cas9 stands a good chance of graduating from the laboratory to the clinic by the end of the second decade of the 21 st century.

However, it might be years, even decades perhaps, before CRISPR technology can be used to make designer babies. Yet the ethical debate is already here. Editing genes through CRISPR practically gives parents the possibility of making selfish choices that are not necessarily in the best interests of their children to be born, especially if the traits that they want to enhance in their future offspring are at the risk of affecting their personalities in other ways, with unforeseen difficulties. Some parents might want to tweak their future offspring's genes in order to boost their intelligence at all costs, or deaf parents might want their children to be deaf like them. As Francis Fukuyama points out, the parents of genetically engineered children could yield to fashions, and thus children could reproach their parents with their design choices. However the proponents of the transhumanist project see this argument as reversible since children could likewise reproach their parents of not having used the technologies at their disposal to rid them of a genetic ailment affecting them or even of not having "enhanced" them because of their religious or moral stands that prevented them from doing it. More frighteningly, tinkering with genes for social or political purposes could theoretically open the door to new forms of social inequality, discrimination and conflict.

\section{The "Promethean Gap" and The New Realities of The Collaborative Economy: From Property Rights to Ownership, From Ownership to Access}

By the end of the second decade of the 21st century the economic development in the globalized world has been characterized by so great technological progress that most commentators call it "revolutionary." However, these technological breakthroughs have come along at the same time with fitful demand, continued spurts of innovation and bouts of austerity since the global financial crisis of 2007-2008. In the end, the question of "obsolescence" is at the heart of the "digital revolution," along with the challenges of artificial intelligence. The corresponding reorganization of global entrepreneurial capitalism has come under the auspices of three groups of major digital companies in three different sectors of activities: GAFA (Google, Apple, Facebook, Amazon), NATU (Netflix, Airbnb, Tesla, Uber) and BAIX (Baidu, Alibaba, Tencent, Xiaomi). Since the "digital revolution" and the development of artificial intelligence are likely to affect almost all the sectors of economic and social life, correspondingly the collective psyche of human societies is set to change deeply, especially in the developed world, along with what Gunther called the human "soul" under the pressure of the "digital revolution."

The spectacular innovations of nanotechnologies, biotechnologies, computer sciences (the big data, connected objects) and cognitivism (artificial intelligence and robotics) have turned some of yesterday's fantasies into tomorrow's credible possibilities. Thus, part of the public is slowly moving away from the ownership of things to mere access to them in the name of what Jeremy Rifkin described as the "collaborative economy." However the "Uberization" of the world which is progressively taking shape with the adhesion of a growing number of people eager to commoditize goods and services that were once for free does not necessarily mean the "obsolescence" of previous economic forms. However, the economy is obviously about to undergo major changes as individual ownership is likely to be replaced by collective access to goods and services, owing to the connectedness of objects from driverless cars to self-controlling houses. 


\subsection{The end of the internal combustion engine and the electrification of energy: the rise of self-driving electric vehicles}

"Human inventiveness ... has still not found a mechanical process to replace horses as the propulsion for vehicles," lamented Le Petit Journal, a French newspaper, in December 1893. Over the next century, the internal combustion engine powered industry provided the propulsion of "horseless vehicles" and changed the world. After World War II, the rich western world societies were rebuilt around motor vehicles, with huge investments in road networks and the invention of suburbia, along with shopping malls and drive-through restaurants. Besides, the car-making industry was also a generator of economic growth and the hallmark of an expanding middle-class throughout the 20th century.

Electric cars are set to replace internal combustion engine ones by the mid-21stcentury. Gains in technology with lithium-ion batteries rapidly widen the range of electric car motors. As of the end of the second decade of the 21st century, the Chevy Bolt has a range of $383 \mathrm{~km}$, a Tesla Model s experimentally covered more than $1,000 \mathrm{~km}$ on a single charge. USB, a Swiss bank, reckons that the "total cost of ownership" of an electric car will reach parity with a petrol one by 2018, and optimistically predict that electric vehicles will make $14 \%$ of global market sales by 2025 , up from $1 \%$ in 2017. Not only are batteries better and cheaper, the cost per kilowatt-hour has already fallen from $\$ 1,000$ in 2010 to \$ 130-200 in 2017 but regulations imposing zero-emission cars are also tightening.

The electrification of cars is likely to change the nature of the automotive industry. Besides being more computerized than petrol cars, electric cars are much simpler and have fewer parts, which means that they need fewer people to assemble them and fewer subsidiary systems from specialist suppliers. Furthermore, with less to go wrong, the market for car maintenance and spare parts is likely to shrink too. New entrants in the car-making industry are likely to be more unencumbered than their predecessors who inherently have costly old factories and swollen workforces. In the future, electric cars premium brands may be able to stand out through styling and handling, but low-margin, mass-market carmakers will probably have to compete chiefly on cost.

Along with the emergence of the electric car, car ownership altogether is likely to be largely replaced by the notion of "transportas a service." In which fleets of cars offer rides on demand. This trend, which is dawning at the end of the second decade of the 21 st century, is likely to develop further with electric propulsion, ride-hailing and self-driving technology. By the most extreme estimates, the notion of "transport as a service" could shrink the car industry by as much as $90 \%$. Lots of shared, self-driving cars would trigger a sort of suburbanization in reverse, allowing cities to replace car parks - making up as much as $24 \%$ of their areas in some cases - by new denser housing, and let people commute from far away as they sleep.

By all means the shift to more effective electric propulsion would obviously offer enormous environmental and health benefits sover the internal combustion engine. The more so, since charging car batteries from central power stations is likely to be more efficient than burning fuel in separate combustion engines. According to America's National Resources Defense Council, existing electric cars in the United States already reduce carbon emissions by $54 \%$ compared with petrol-powered ones. And such a reduction is likely to grow as electric vehicles become more efficient and grid-generation becomes greener. It is worth noting that the World Health Organization sees outdoor air pollution as the single largest health risk contributing to $3.7 \mathrm{~m}$ deaths a year.

The rise of the electric car is also likely to trigger geopolitical consequences affecting oil and the procurement of lithium carbonate, cobalt and rare-earth elements for electric motors. The oil industry may be divided about when to exactly expect global peak oil demand but no oil company wants to be left with useless oil in the ground in the future. Thus, a dearth of new investments is likely, especially in new, high-cost areas such as the Arctic. By contrast, producers like Saudi Arabia, with vast reserves that can be tapped cheaply, will be under pressure to get pumping before it is too late. The Middle East will probably still matter but a lot less than it did before the rise of the electric car. Additionally, volatile oil prices are likely to make it more difficult for hydrocarbon revenues to fill the national coffers of some countries, especially those where the struggle for power has long been about controlling oil wealth. Lithium is used not just to power cars. It is also used for giant batteries to store energy when demand is slack and 
release it as it peaks. The price of lithium carbonate has risen from $\$ 4,000$ a ton in 2011 to more than $\$ 14,000$ in 2017. However, since electric cars are unlikely to consume the lithium used in their batteries in the 21 st century in the same proportions that internal combustion engines consumed oil in the 20th century, the geopolitical impact of the search for it in the 21st century is likely to be different from the search for oil in the 20th century. Indeed, old lithium-ion batteries from cars can be reused in power grids, and then recycled. Besides, the internal combustion engine will probably continue to dominate shipping and aviation for decades to come.

Electric motors will eventually be cheaper and cleaner, offering more freedom and convenience internal combustion engines. Besides, driverless, electric cars in the 21 st century are likely to improve the world in profound and unexpected ways just as internal combustion engines did in the 20th century. Old factory jobs in the automotive industry are likely to disappear in the midst of social turmoil, which would require some form of state intervention to soften the impact of the redundant workers' joblessness. In addition, policymakers will also have to ensure that countries have enough generating capacity and set new rules and regulations for public recharging stations, the recycling of batteries, rare-earth motors and other components in "urban mines" [72].

\subsection{The challenges to property rights in the "digital age"}

Digital devices are challenging the nature of ownership. As a matter of fact, ownership in the "digital age" is no longer as straightforward as writing a check. Before the advent of the "digital age", "if you bought something, you owned it for good. If you broke it, you fixed it. If you no longer wanted it, you sold it or chucked it away. " Of course, by the end of the 20th century, some firms made money "on the aftermarket, using warranties, authorized repair shops, and strategies such as selling cheap printers and expensive ink." However, those profit-making strategies flourishing in the 20th century did not challenge the very nature of ownership, whereas the incorporation of digital devices into products changed what it means to be an owner by the end of the second decade of the $21 \mathrm{st}$ century. By then indeed, the owners of some products had to acknowledge the fact that there were limitations to their ownership. For instance, Tesla electric car drivers learned after buying their electric vehicles that the company's CEO Elon Musk had forbidden them from using their cars to work for ride-hailing firms such as Uber. Likewise, the owners of John Deer tractors found out that they were "recommended" not to tinker with the software that controlled them. "In its" License Agreement for John Deere Embedded Software ", the company retains ownership of the software programs. It also refers to the Digital Millennium Copyright Act, a controversial piece of legislation that makes it illegal for customers to circumvent copy protection." And yet, it can be necessary to develop diagnostic tools for devices, which is the reason why the John Deere Tractor Company requires that its customers use only authorized software in specific repair shops, which may send tractor owners located kilometers away. Such a requirement can be commercially devastating or encouraging the use of hacked software from Eastern Europe or elsewhere. More generally, since the advent of smartphones, the users of those products had to accept that they did not control the software in their devices. As a matter of fact, this situation boils down to the fact that consumers are only licensed to use the products that they own. This means that who owns and who controls which objects has become unclear by the end of the second decade of the 21 st century.

Originally, when digital devices were incorporated into their products, manufacturers had first sought for good reason to restrict what owners would do with increasingly complex technology. Indeed, some types of gear, such as photocopiers or medical equipment had always been hard to mend because of their internal complexity. Thereby, manufacturers meant to protect their copyrights to ensure that their machines did not malfunction, upheld environmental standards or were prevented from being hacked. In other words, manufacturing companies used their control over a product's software for the owner's benefit. This ethical practice has not disappeared altogether. For instance, when Hurricane Irma hit Florida in September 2017, the electric car Tesla Company remotely upgraded the software controlling the batteries of some of its models to give their owners more range to escape the storm. However, what had been the exception has become the rule by the end of the second decade of the 21 st century. "A John Deer tractor comes with millions of lines of software code, controlling everything from the engine to the armrests. Mobile devices, for their parts, are getting ever more densely packed to make them smaller and able to accommodate new components. Thus, "the more digital strings are attached to goods, the more the balance of control 
tilts towards producers and away from owners." On the one hand, the product's use is limited by the producer and on the other hand what data the owner must surrender leads to more built-in obsolescence. Furthermore, all sorts of items, from smartphones to washing machines "have become exceedingly hard to fix, meaning that they are thrown away instead of being repaired." For instance, Samsung's Galaxy Note 8 is mainly held together with glue, but makes repairs more difficult.

In addition, the ownership of connected objects challenges the privacy of owners. For instance, a robotic vacuum cleaner will create a digital map of its owner's home interior that can then be sold on to advertisers. Hackers of connected objects can record highly personal information about their owners or sabotage their normal use at their expense, sometimes putting their lives at risk. Intrusions On the ownership of connected objects call for the protection of their owners' property rights. By the end of the second decade of the 21 st century, the owners of connected objects have begun to organize and to fight on three fronts: 1) the right too tinker with their own property; 2) the right to modify it if they wish to; 3) the right to control who uses the data collected by the digital devices incorporated in their property. Thus, a "right to repair " has emerged in some American States and in the European Parliament, which want manufacturers to make goods such as washing machines more fixable. In France, appliance-makers are required to tell buyers how long a device is likely to last, which is a sign of how repairable it is. New Marketing strategies based on the sustainability of products are emerging. Thus, in counterpoint to planned obsolescence and a throwaway consuming culture according to which the average lifetime of a washing machine is eight years, a French startup bets on making money with a washing machine called "L'increvable" (the indestructible) designed to last for 50 years [73].

Generally, regulators should restore competition by insisting that independent repair shops have the same access to product information, spare parts and repair tools as manufacturer-owned ones, as is already the case in the car industry. "Gadgets, by and large, are sold on the basis that they empower people to do what they want. To the extent they are controlled by somebody else, the nature of ownership is changed. " [74]

\subsection{From mutualism to the collaborative economy}

In a way, the principles of the "collaborative economy" and of the "sharing economy" in the 21 st century are continuations of the mutualistic movement in the 20th century. Indeed, the core idea of mutualism was to provide a collective answer to individual needs that individuals could not meet on their own, especially in terms of risk management and health care. In the 21stcentury, car-hailing or home swapping provide for the risk of not owning a car or a place when traveling. Likewise, the existence of a community, through a mutual or an online site produces economic value, which in turn fosters cooperation, sharing or donation between its members. In other words, the "digital society" has rekindled the values of the mutualistic movement in the 20th century. For instance, while the French car-hailing startup Blablacar, which connects drivers and passengers who share the cost of the ride, operates as a mutual, the Uber car-hailing company functions as a capitalistic venture aiming primarily at turning out a profit from the cost of the journey. When Blablacar gets into the business of car-pooling between home and office, it aims at social innovation through the reduction of carbon emissions and contributes to the environmental transition to thwart the effects of climate change [75].

The "makers", like the "survivalists" [76] or the zadistes [77] believe in collaborative consumption as opposed to mass consumption, in community rather than brand names. They favor "new economic models based on shared resources and collective consumption." Somewhat naïvely, they think that they represent a switch from "Generation Me to Generation We" [78]. Thus, the proponents of the "collaborative economy" form communities that are not structured as the tribes of yore since their members join them of their own freewill. In all cases, the aim of the "collaborative economy" is to produce and exchange all the goods and services that are necessary to the wellbeing and the subsistence of those who adopt it, and to short-circuit the intermediaries of the traditional capitalist economy. A self-reliance of sorts and an exponential network of small communities structured by the four Internet structures is supposed to "empower" the people of the "third sector," thus leading to "the end of capitalism," coupled with the previously-heralded "End of work", thanks to the digitalization of the world and the GAFA firms aiming at strategies 
tending to a zero marginal cost [79] and the march of the robots destroying human work [80], according to Jeremy Rifkin.

However, the "trickle-down" of the high-tech firms in a few markets, the irenic visions of a future "techno-paradise," with the globalization of the "social economy" that Rifkin predicted in 1995, have anything but materialized with the development of the so-called "collaborative economy," which turns out to be anything but a demise of global capitalism. Quite the contrary, Schumpeter's notion of "creative destruction" and the Schumpeterian growth theory [81] is still relevant in four important aspects: 1) the role of competition and market structure; 2) firm dynamics; 3) the relationship between growth and development with the notion of appropriate growth institutions; 4) the emergence and impact of long-term technological waves [82]. Unfortunately, unlike Wikipedia, which is a free, non-profit network, the so-called "collaborative economy," is not up to the expectations of the "progressive and optimistic" visions of the libertarian left of the 1960s.

Capitalism is certainly not dead. Quite the contrary, never in human history has there been such a commercialization and commodification of human activities. Generations $\mathrm{Y}$ and $\mathrm{Z}$ are not a bit more emphatic than their predecessors. Quite the contrary: The University of Michigan has recently conducted an inquiry with standardized questions over 14,000 students that shows that empathy for others has decreased by $40 \%$ compared to previous generations. Therefore, the young who are eagerly embracing what the so-called "collaborative economy" has to offer do not act on some utopian impulse to create new peer-to-peer economic relations but simply because they are cheaper. Who really cares if the traditional taxi driver has lost his job to Uber? Who cares if the junior middle school teacher turns into a taxi driver after classes to make ends meet? "Let's Uber." And who cares about Uber after Travis, its former $\mathrm{CEO}$, had to give up his job under a number of accusations that have damaged the image of a startup that was almost the symbol of a new frontier for a while.

Deregulation goes hand in hand with the libertarian idea of eliminating unnecessary intermediaries and living at a lesser cost. The so-called "collaborative economy" has nothing to do with JeremyRifkin's utopian vision of some collective, global appropriation of NBICs by self-reliant, connected, independent communities of empowered people around the world. The so-called "collaborative economy" does not in the end favor "access" over "ownership," "care" over selfish greed, "collectivism" over "individualism." Instead, it has managed to commercialize and commodify what was for free in the days of yore, such as lending an apartment, a car, delivering household services. The "collaborative economy" has in fact turned into an ultraliberal, hyper capitalistic project that must be regulated like the potentially reversible genetic "enhancement" of the humankind. The transhumanist project and the so-called "collaborative economy", which share the same origins, that is to say the convergence of the NBICs, along with a libertarian dream need to be submitted to some forms of regulation, if the humankind is to survive in its present form as a species among others, a paradox in a globalized deregulated knowledge-economy.

\section{Conclusion}

Algorithms are everywhere: they play the stock market, decide if you deserve a mortgage and may one day drive your car for you. Essentially, they are sets of precise steps that need no great mental effort to follow but which, if obeyed exactly and mechanically, will lead to some desirable outcome. This makes them ideal for performing tasks which humans generally find frustrating [83]. Instruments outperform humans. The latter cannot collectively fully figure out a representation of the "perfection" of the products that the innovative Knowledge-economy has been capable of churning out for better and worse by the end of the second decade of the 21 st century. The resulting "Promethean gap" between the limits of human representation and the powerfulness of algorithms-controlled production in the 21 st century has continued to modify the human mind in the ways that Gunther Anders had noted after the scientific breakthroughs and moral disasters associated with the tragic outcomes of the second industrial revolution in World War II. Whether the ubiquity of algorithms produces a 4.0 "digital society," or simply alters the evolution of the "third industrial revolution" in the 21 st century is secondary question when its comes to examining the "obsolescence of Man" and the "mutation" of the humankind in the light of the transhumanist project. The distinction between curing and enhancing the field of medicine becomes blurred, just as in the production line the 
performances of the human body and that of robots are becoming "collaborative" with the advent of "cobots," which raises the question of the interface between man and machine and the externalization of human intelligence. Whatever the motivations of the beneficiaries in their quest for power, a "genetically modified" human "species" with "enhanced" characteristics would produce an unbridgeable "Promethean gap" in the hearts and minds of the human kind, as it was known before. Perhaps we should bear in mind that Neanderthals became heredity because of the genetic superiority of Cro-Magnon.

Internationally concerted, intelligent regulation is certainly highly desirable to help chart out the economic and managerial ways to accommodate innovation in the "ubiquitous society," and to define the reasonable courses that can template the effects of the "obsolescence of Man" and its effects on the human kind in the foreseeable future. Governments and regulators are not powerless when confronted with the deeds of the tech giants' communication empires at the end of the second decade of the 21 st century. First, governments do have bargaining power when they decide to exert their regal functions within the context of fighting terrorism at home and abroad. If encryption is necessary to maintain the cyber-security of online transactions, the tech giants of communication have somehow to bow to governments' demands, and yield vital access to crucial information to governments in the global "asymmetrical war" that terrorist organizations wage against a number of states throughout the world. Silicon Valley itself, whatever the strength of its global reach through innovation and financial power is part of a State that protects and nourishes it. If, logically, Mark Zuckerberg himself, the CEO of Facebook, sometimes dreams of becoming the next President of the United States, the presidential function has to accommodate American public opinion. Terrorism has become a sensitive issue that dramatically affects the lives of the public in democracies and it is a state of things that is likely to last for at least a generation according to some estimates. Second, governments and regulators do have the power to curb the financial profits of the new tech communication giants to their advantage through the mechanism of taxation. For instance, the French government for its part has reacted under the impulse of its young president to the de facto domination of the new communication empires in 2017 by laying down the principle that the tech companies, which so far had largely evaded taxation should be taxed where they make a profit, not just in the country where their headquarters are registered. Thus, the tech giants turning out a profit in France should be taxed in France, not just in low-tax countries like Ireland or Luxembourg, where they are registered to operate at low cost within the European Union. Thirdly, regulators should reaffirm loud and clear that the deontological rules of journalism should apply in cyberspace where they are largely ignored or baffled, especially on social networks. Thus, the lack of deontological control on social networks has lead to blatant manipulations through the production of "post-truth lies" and "fake news" or to unfounded discussions over alleged suspects even before the authorities could start a proper inquiry as was the case after the Las Vegas shoot-out in October 2017.

These days, young people interact in online communities. They construct their identities in various social contexts: social, fantasy, role-playing; and for various social purposes: leadership, learning, power, rebellion and romance. They deploy both visual literary cues to develop a full sense of presence online, and to effectively communicate with their peers. Thus they make sense of their own identities and their place within broader communities. According to Philosopher Michel Foucault, we are constructed as "subjects" in the real world. Under the online "panoptic" gaze of a virtual "disciplinary society" characterized by the rise of the "big data" which is recorded, stored and analyzed, the surveillance on us denies the seeming anonymity of cyberspace. However, the virtual world offers us a chance to subvert and challenge these constructions since we can create alternative (real or fictitious) online identities of ourselves. This has led to a more prolific engagement in alternative constructions of the self, especially through the use of images and avatars as a significant semiotic resource for identity construction in online spaces. In addition, French academic and philosopher Michel Serres sees the advent of a mutant digital generation that has already begun to challenge the former relation patterns to information, knowledge, authority and communities of belonging in the context of the global "ubiquitous society". Traditionally, the theory was that children learned through interaction with expert others [84]. In the virtual world, "digital native" children do learn from more experienced others, but more often than not they also learn without an expert, using strategies such as brainstorming, trial and error, practice, and discussion. They learn through the process of becoming a community and engaging in its social and discursive practices. They learn through adopting identities mediated through text, image and sound, both within and out of their 
fantasy storylines. They learned through the repeated routines and activities that they construct together, and they learned through ongoing interactions with each other [85]. These ways and means for learning resonate closely with Wenger's notion of "Communities of Practice" [86].

The notion that knowledge and basic research turn into innovation under the pressure of socio-economic needs is hardly new in this part of the world. Chinese culture had discovered the compass, powder, paper and the wooden printing press, a long time before Europe turned them into more sophisticated navigation instruments, gunpowder for big guns and printed books. That, in turn, brought about the Revival of learning, Reformation, humanism, hard sciences and ultimately democracy in the West at the time Xu Guanji and Mateo Ricci were engaged in an intellectual exchange that could have potentially re-orient Chinese culture towards hard sciences and technology. Today's digital natives have immediate access to information and exert their fluid intelligence capabilities through the "new screens" from infancy. The human brains have adapted for the past million years and will certainly continue to do so in this day and age, only because technology per sehas has always been part of human beings. The contemporary world wide Web, big data and social networks look like yet another externalization of the human body. Indeed, they function like an extension of the nervous system that simultaneously irrigates the virtual and the real worlds. In some ways, the new ubiquitous connectedness means that like Saint Denis, the first bishop of Paris decollated on the hill of Montmartre, people go about their daily lives carrying their heads around in the form of a mobile telephone or an i-pad a well -made and a well-filled head at that. However, access to information is a matter of communication, whereas acquiring knowledge largely remains a matter of transmission, a painful or painless construct, through the process of learning something that traditional Chinese culture reckoned would take a hundred years.

\section{References}

[1] Günther Anders, L'Obsolescence de l'homme. Sur l'âme à l'époque de la deuxième révolution industrielle (1956, Die Antiquiertheit des Menschen: über die Seele im Zeitalter der zweiten industriellen Revolution (CH Beck Verlag: München) (trd. De l'allemand par Christophe David, Paris: Editions de l'Encyclopédie des Nuisances, Editions Ivrea, 2002).

[2] Günther Anders, L'Obsolescence de l'homme. Sur l'âme l'époque de la deuxième révolution industrielle(1956, Die Antiquiertheit des Menschen: über die Seele im Zeitalter der zweiten industriellen Revolution(CH Beck Verlag: Munich), trad. de l'allemand par Christophe David, Paris: Editions de l'Encyclopédie des Nuisances, Editions Ivrea, 2002), p. 48.

[3] Michel Foucault, Surveiller et punir: naissance de la prison (Paris: Gallimard, 1975).

[4] Marc Groenen, André Leroi-Gourhan: essence et contingence de la destinée humaine (Paris: De Boeck Université, 1996); André Leroi-Gourhan, Évolution et techniques (Paris: A Michel, 1943-45); Le fil du temps (Paris: Fayard, 1983)

[5] Jack Goody, The domestication of the savage mind (Cambridge, UK, New York: Cambridge University Press, 1977, 1988); Literacy in traditional societies (Cambridge: Cambridge University Press, 1968)

[6] Günther Anders, L'Obsolescence de l'homme. Sur l'âme à l'époque de la deuxième révolution industrielle (1956, Die Antiquiertheit des Menschen: über die Seele im Zeitalter der zweiten industriellen Revolution (CH Beck Verlag: München), trd. De l'allemand par Christophe David, Paris: Editions de l'Encyclopédie des Nuisances, Editions Ivrea, 2002), p. 31

[7] Günther Anders, L'Obsolescence de l'homme. Sur l'âme à l'époque de la deuxième révolution industrielle (1956, Die Antiquiertheit des Menschen: über die Seele im Zeitalter der zweiten industriellen Revolution (CH Beck Verlag: München), trd. De l'allemand par Christophe David, Paris: Editions de l'Encyclopédie des Nuisances, Editions Ivrea, 2002), p. 32.

[8] "Cobots -Your plastic pal who's fun to be with. If robots are to work with people, they must understand how people work", Science and Technology, The Economist, August 19th2017, p. 59.

[9] Daniela Rus, "The Robots Are Coming. How Technological Breakthroughs Will Transform Everyday Life ", Foreign Affairs, p. 2.

[10] John Maynard Keynes, The general theory of employment, interest and money (London, Macmillan and co., 1936).

[11] Wassily Leontief and Faye Duchin, The future impact of automation on workers (New York: Oxford University Press, 1986)

[12] Alfred Marshall, Elements of economics of industry, being the first volume of Elements of economics, 2nded. (London and New York: Macmillan and co., 1892).

[13] See Joel Mokyr, ed., The British industrial revolution: an economic perspective (Boulder, Colorado: Westview Press, 1993). 
[14] Claudia Goldinand Lawrence F Katz, The Race between Education and Technology (Harvard University Press, 2010).

[15] Boyan Jovanovic, Peter L. Rousseau, General purpose technologies (Cambridge, Mass .: National Bureau of Economic Research, 2005); George R.G. Clarke, Christine Zhenwei Qiang, and Lixin Colin Xu, Internet as a general-purpose technology: firm-level evidence from around the world (Washington, D.C .: World Bank, 2015).

[16] Nicolas Bouzou, On entend l'arbre tomber mais pas la forêt pousser (Paris: Jean-Claude Lattès, 2013).

[17] Nicolas Bouzou, Le chagrin des classes moyennes (Washington, D.C .: World Bank, 2015)

[18] Brenda Morgan-Klein and Michael Osborne, The concepts and practices of lifelong learning (London, U.K .; New York: Routledge, 2007); Norman Longworth and Michael Osborne, eds., Perspectives on learning cities and regions: policy, practice, and participation (Leicester: NIACE, 2010).

[19] Michael A. Osborne and Carl Benedikt Frey, "Abstract", The Future of Employment: How susceptible are Jobs to Computerization? September 17, 2013

[20] Andrew Sheng, «Disruptive Donald upsets the odds,» The China Post, Saturday, November 12, 2016, p. 4.

[21] A. C. Pigou, Employment and equilibrium; a theoretical discussion (London: Macmillan, 1952); The economics of welfare (London: Macmillan, 1952).

[22] "Human capital. The people's champion. Gary Becker made humans the central focus of economics ", The Economist, August 5th, 2017, pp. 51-52.

[23] Gary S. Becker, Human capital: a theoretical and empirical analysis, with special reference to education (Chicago: University of Chicago Press, 1980, 1975); Human capital and the personal distribution of income; an analytical approach (Ann Arbor, Institute of Public Administration, 1967); Gary S. Becker, Kevin M. Murphy, Robert F. Tamura, Human capital, fertility, and economic growth (Cambridge, MA: National Bureau of Economic Research, [1990]).

[24] Hartmut Lehmann and Guenther Roth, Weber's Protestant ethic: origins, evidence, contexts (Washington, D.C.: German Historical Institute; Cambridge, England; New York, N.Y.: Cambridge University Press, 1993).

[25] "Innovation in China. The next wave. A new generation of Chinese entrepreneurs will have a powerful impact on industries and consumers worldwide", The Economist, September 23rd 2017, pp. 18-20.

[26] Adam Smith, LL.D. and F.R.S., formerly Professor of moral philosophy in the University of Glasgow; in two volumes, An inquiry into the nature and causes of the wealth of nations (London: Printed for W. Strahan and T. Cadell, in the Strand, MDCCLXXVI [1776]).

[27] Gary S. Becker, The economic approach to human behavior (Chicago: University of Chicago Press, 1976).

[28] "Human capital. The people's champion. Gary Becker made humans the central focus of economics ", The Economist, August 5th, 2017, p. 52.

[29] Laurent Alexandre, La guerre des intelligences (Paris: JC Lattès, 2017).

[30] "The power of algorithms: brick by brick," The Economist, Daily Dispatch, Wednesday, August, 30 th 2017.

[31] Franklin Foer, World Without Mind: The Existential Threat of Big Tech (Penguin Press, Jonathan Cape, 2017)

[32] Martin Heidegger, Question IV translated into French by Jean Beaufret and François Fédier (Gallimard: Paris, 1976 ), p. 114.

[33] Jonathan Taplin, Move Fast and Break Things - The damage done by Silicon Valley (London: Penguin Books, 2017).

[34] Jack Goldsmith and Tim Wu, Who controls the Internet? Illusions of a borderless world (New York: Oxford University Press, 2006).

[35] Tim Wu, The Master Switch: the rise and fall of informative empires (New York: Alfred A. Knopf, 2010)

[36] Tim Wu, The attention merchants: the epic scramble to get inside our heads (New York: Alfred A. Knopf, 2016)

[37] "The myth of cyber-security. Computers will never be secure. To manage the risks, look to economics rather than technology, "The Economist, April 8th 2017, p. 9.

[38] "DNA and insurance. The gene is out of the bottle. Insurers worry that genetic tests might one day ruin their business ", The Economist, August 5th2017, p. 57. 
[39] Günther Anders, L'Obsolescence de l'homme. Sur l'âme à l'époque de la deuxième révolution industrielle (1956, Die Antiquiertheit des Menschen: über die Seele im Zeitalter der zweiten industriellen Revolution (CH Beck Verlag: München) (trd. De l'allemand par Christophe David, Paris: Editions de l'Encyclopédie des Nuisances, Editions Ivrea, 2002 ), p.33.

[40] Ibid., P. 34.

[41] André Pichot, La société pure, de Darwin à Hitler (Paris: Flammarion, 2001).

[42] Sir James Jeans, Sir William Bragg, E. V. Appleton, E. Mellanby, John Burton Sanderson Haldane, Scientific progress (New York: Macmillan, 1937)

[43] Nicolas Le Dévédec, La Société de l'amélioration. La perfectibilité humaine, des Lumières au transhumanisme (Paris: Liber, 2015)

[44] Helen Bequaert Holme and Laura M. Purdy, eds., Feminist perspectives in medical ethics (Bloomington: Indiana University Press, 1992).

[45] Nick Bostrom and Julian Savulescu, "Human enhancement ethics: the state of the debate" inMihail C. Roco and William Sims Bainbridge, Converging Technologies for Improving Human Performance -Nanotechnology, Biotechnology, Information Technology and Cognitive Science (Dordrecht; Boston: Kluwer Academic Publishers , 2003).

[46] C. A. J. Coady "Playing God" inMihail C. Roco and William Sims Bainbridge, Converging Technologies for Improving Human Performance - Nanotechnology, Biotechnology, Information Technology and Cognitive Science (Dordrecht; Boston: Kluwer Academic Publishers, 2003).

[47] Erik Parens "Toward a more fruitful debate about enhancement"; Arthur L. Caplan "Good, better, or best?" in Mihail C. Rocoand William Sims Bainbridge, Converging Technologies for Improving Human Performance - Nanotechnology, Biotechnology, Information Technology and Cognitive Science (Dordrecht; Boston: Kluwer Academic Publishers, 2003).

[48] Julian Savulescu, "The human prejudice and the moral status of enhanced beings: what do we owe the gods?" in Mihail C. Roco and William Sims Bainbridge, Converging Technologies for Improving Human Performance - Nanotechnology, Biotechnology, Information Technology and Cognitive Science (Dordrecht; Boston: Kluwer Academic Publishers, 2003).

[49] Mihail C. Roco and William Sims Bainbridge, Converging Technologies for Improving Human Performance Nanotechnology, Biotechnology, Information Technology and Cognitive Science (Dordrecht; Boston: Kluwer Academic Publishers, 2003).

[50] Luc Ferry, La révolution transhumaniste. Comment la technomédecine et l'uberisation du monde vont bouleverser nos vies (Paris: Plon, 2016), pp. 47-48.

[51] Nicolas de Condorcet, Esquisse d'un tableau historique de progrès de l'esprit humain ([1795] Paris: Éditions sociales, coll. «Les classiques du peuple», 1966), p. 255.

[52] Luc Ferry, La révolution transhumaniste. Comment la technomédecine et l'uberisation du monde vont bouleverser nos vies (Paris: Plon, 2016), pp. 53-60.

[53] "pt. II. Human enhancement: the somatic sphere --pt. III. Human enhancement: the cognitive sphere, "inMax More and Natasha Vita-More, eds., The transhumanist reader: classical and contemporary essays on the science, technology, and philosophy of the human future (Chichester, West Sussex, UK: Wiley-Blackwell , 2013).

[54]"Pt. V. Engines of life: identity and beyond death "inIbid.

[55] Tahsin Jarac, trans. Les dieux et les hommes; ou, Gilgamesh (Tanrilar ve insanlar (Gilga-meş)) (Ankara: Ayyildiz Matbaasi, 1961); Rivkah Schärf Kluger, The Archetypal significance of Gilgamesh: a modern ancient hero, H. Yehezkel Kluger, ed. (Einsiedeln, Switzerland: Daimon, 1991).

[56] Laurent Alexandre, La Mort de la mort (Paris: Jean-Claude Lattès, 2011).

[57] Guy Vallancien, La Médecine sans médecin? Le numérique au service du malade (Paris: Gallimard, 2015).

[58] "pt. VI. Enhances decision making "in Max More and Natasha Vita-More, eds., The transhumanist reader: classical and contemporary essays on the science, technology, and philosophy of the human future (Chichester, West Sussex, U.K.: Wiley-Blackwell, 2013).

[59] "pt. VII. Biopolitics and policy" in Ibid.

[60] Allen Buchanan et al., From chance to choice: genetics and justice (Cambridge, U.K.; New York: Cambridge University Press, 2000) 
[61] Pramod K. Nayar, Posthumanism (Cambridge: Polity, 2014)

[62] “pt. VIII Future trajectories: singularity, "“ pt. IX The world's most dangerous idea, ”inIbid.

[63] Ray Kurzweil, The Singularity is near. When humans transcend biology (Penguin Books, 2005)

[64] Hans Moravec, Robot, their machine to transcend mind (Oxford: Oxford University Press, 1999).

[65] Pramod K. Nayar, Posthumanism (Cambridge: Polity, 2014)

[66] "Editing humanity," The Economist, August 22nd, 2015, p. 11.

[67] "Extinctions to order," The Economist, September 17th 2016, p. 16; “The Zika virus,” The Economist, September 17th 2016, pp. 70-71;

[68] "Genetic engineering. DNA and how to adjust it. Researchers are getting better at tweaking the genomes of human embryos ", The Economist, August 5th2017, p. 59.

[69] "Roadkill - The internal combustion engine had a good run. But the end is in sight for the machine that changes the world, "The Economist, August 12th2017, p. 7.

[70]Nathan Grass, "L'Increvable, la machine à laver qui vous ne lâchera jamais”, Les Suricates.fr, 18/02/2016; http://lincrevable.com

[71] "Property in the digital age. Take back control. Digital devices are challenging the nature of ownership. It's time to fight back "), The Economist, September 30th 2017, p. 16; "Tinkering in the digital age. If it's broken, you can't fix it. Software is making things harder to mend. Some are calling for a "right to repair", "The Economist, September 30th 2017, p. 58-59.

[72] Luc Pierron, «Le mutualisme, une idée pleinement moderne», Valeurs mutualistesn ${ }^{\circ}$ 308, September 2017 , p. 11.

[73] Survivalists or preppers are individuals or groups of individuals who are actively preparing for emergencies, including possible disruptions in social or political order, on scales from local to international. Survivalists often acquire emergency medical skills and self-defense training. They prepare to become self-sufficient and tend to build structures that would allow them to survive a catastrophe.

[74] In France, the word designates militants, whose goal is to "defend" an area to block the construction of an infrastructure that they disapprove of for economic or political purposes.

[75] Rachel Botsman and Roo Rogers, What's mine is yours: the rise of collaborative consumption (New York: Harper Business, 2010); Michel Lallement, L'âge du faire (Paris: Le Seuil, 2015)

[76] Jeremy Rifkin, The zero marginal cost society: the internet of things, the collaborative commons and the eclipse of capitalism (New York: Palgrave Macmillan, 2015).

[77] Jeremy Rifkin, The end of work: the decline of the global labor force and the dawn of the post-market era (New York: G.P. Putnam's Sons, 1995).

[78] Von dr. Joseph Schumpeter, Theorie der wirtschaftlichen entwicklung (Leipzig, Duncker \& Humblot, 1912); Joseph A. Schumpeter, Capitalism, socialism, and democracy, introduction by Thomas K. McCraw (New York: Harper Perennial 2008).

[79] Philippe Aghion, Ufuk Akcigit, Peter Howitt, What do we learn from Schumpeterian growth theory?(Cambridge, Mass. : National Bureau of Economic Research, 2013)

[80] "The power of algorithms: brick by brick," The Economist, Daily Dispatch, Wednesday, August 30th 2017.

[81] L. Vygotsky, “The Genesis of Higher Mental Functions” in The Concept of Activity on Soviet Psychology, J. V. Wertsch, ed., (New York: M. E. Sharpe, 1981)

[82] Angela Thomas, Youth online: identity and literacy in the digital age (New York: Peter Lang Publishing, Inc., 2007$)$, p. 2.

[83] E. Wenger, Communities of Practice: Learning, Meaning, and Identity (London: Cambridge University Press, 1998) 